\title{
Witchcraft and the Somerset Idyll: The Depiction of Folk Belief in Walter Raymond's Novels ${ }^{1}$
}

\author{
Abstract \\ The work of Walter Raymond (1852-1931) is now largely forgotten. Yet his Somerset \\ novels, complemented by his ethnographic writings, contain depictions of local \\ witchcraft belief that are worthy of study in literary and historical contexts. They raise \\ issues regarding the fictional depiction of rural life and tradition, and the value of fiction \\ as a folkloric and historical source.
}

In her guide A Gentlewoman's Home (1896), the pioneering domestic journalist and interior decorator Jane Ellen Panton (1847-1923) gave advice on the sort of literature that should line the shelves of a bachelor's room. Above the head of the bed the bookcase should be 'very carefully filled with light and amusing literature'. She recommended that Walter Raymond's 'charming Somersetshire idylls should not be forgotten', praising his novels Love and Quiet Life and Tryphena in Love 'as jewels, the delightful ever-changing gleams from which should go far to illuminate the darkness which has of late appeared to be gathering round the head of the regulation English novel' (Panton 1896, 397). In the same year Love and Quiet Life was included in Charles Dudley Warner's Library of the World's Best Literature (1896), where Raymond was described as 'a faithful student of the West Country folk, and he has presented a truthful picture of a phase of English life which he realized to be rapidly passing away'(Warner 1896, 155).

Born into a modest glove-manufacturing family in Yeovil in 1852, as a young man Raymond picked up much rural lore and gossip as he toured the villages of the region dealing with the cottagers who did piecework glove-stitching for the firm. Inspired in part by the dialect poetry of the North Dorset clergyman and philologist William Barnes (1801-1886), Raymond's literary goal was to capture the idiom and life of the 'common people' of Somerset. His first novel Misterton's Mistake (1889), which was only partly set in Somerset, was, in Raymond's own words, 'a dismal failure. It was a bitter pill to me, and I took a long time to get over the disappointment' ('The author who avoids the Cities', 1928). He wrote under the pseudonym Tom Cobbleigh for his third, purely Somerset-located novel Gentleman Upcott's Daughter (1892), but struggled to find a publisher until Unwin took it on. It was a commercial and literary success, his writing career was launched, and he withdrew from the glove-making business. By 1896 Raymond had published some seven novels, and contributed to numerous magazines and periodicals, including Country Life.

The rural idyll novel was in vogue. While during the first two thirds of the nineteenth century there had been numerous literary expressions of a notional timeless rural rusticity, in contrast to the rapidly spreading industrial-urban landscape, the late nineteenth century and early twentieth century generated fiction that tried to portray the 'real' everyday life of rural folk, reflecting custom and tradition, and, in particular, a sense of local and regional identity (see, for example, Burchardt 2002, chap. 6). Hardy's Wessex novels set the template and others followed, such as Constance Holme's Lancashire novels, Eden Phillpott's Dartmoor romances, Sabine Baring-Gould's local picaresque stories based on his various clerical positions around the country, and Mary Webb's Shropshire novels. The same trend has been identified elsewhere. In Germany 
some 194 Bauernromanen (rustic novels) were published by 113 different authors between 1871 and 1918 (Blum 1982,123). Few novelists of the rural were interested in the sort of social polemic and Darwinian project behind Emile Zola's rural novel $\mathrm{La}$ Terre (1887). They were for the most part, Raymond included, writing homages to what was a vanishing way of life, a transformation that was considered a regrettable consequence of general societal progress. Influenced by and often working with folklorists and folk-song collectors (Raymond helped Cecil Sharp in his collection of Somerset folk songs for instance), the rural romancers sought to capture the survivals of a disappearing traditional culture and its distinctive regional manifestations. At their best some of the novels can be read, as Keith Snell puts it, as 'informal ethnography' $(1998,23)$. Yet the consequences of this late nineteenth-century romantic impulse raise numerous interpretive problems in terms of the nature of folk revival, the reinvention of tradition, and the verisimilitude of portrayals of rural life (see Boyes, 1993; Bennett 1994; Harker 1985; Bearman 2000; Howkins 1986).

Raymond's use of locality, folklore, and dialect to depict rural culture inevitably led to comparisons with his illustrious Dorset neighbour Thomas Hardy. There is no evidence the two men ever met, though Raymond reviewed Hardy's work in the press, and Hardy once sent an appreciative letter to Raymond following a recitation of William Barnes's poetry he had given in Dorchester. Raymond recommended Hardy's work to the young novelist John Cowper (1872-1963), whose clergyman father was posted to a Somerset parish in the early 1890s (Clark 1933, 37; Keith 2006, 271). During the late nineteenth century Raymond's literary reputation was far from overshadowed by Hardy regionally, and he was spoken of in favourable, comparable terms nationally. In his History of the English Novel (1924) Ernest Albert Baker, for example, described Raymond's Two Men o' Mendip (1899), as 'a very respectable effort in the Hardy vein'(Baker 1924, 95). In 1934 the Western Morning News noted that he had been called the Hardy and the Barrie of Somerset (C.D.B. 1934). Raymond's death in 1931 led to the creation of a memorial fund to pay for the republication of his work by J. M. Dent publishers. But move on a few decades and Raymond was largely forgotten locally, erased from the pages of literary scholarship, and comparison with Hardy flatly dismissed. In a 1986 article the Somerset author Berta Lawrence noted Raymond's considerable talent, but called any comparisons with Hardy misguided: 'To compare Hardy and Raymond is to compare a giant with a pigmy' (Lawrence 1986, 35). Yet, such a comparison, however inevitable, is unfair. While Raymond's literary talent was not the equal of Hardy's in terms of lyrical fluency and psychological depth, the aim of capturing local culture was sometimes admirably achieved in his work. With regard to the portrayal of witchcraft belief he is a rare and insightful literary chronicler, generally resisting the temptation to over-dramatize or romanticize its place in rural culture.

\section{The Representation of Witchcraft Belief and Witches}

Witchcraft and the figure of the witch were no strangers to nineteenth-century novels. But until Hardy and Raymond the image and representation was largely in the vein of fairy-tale and Gothic representations such as Johann Wilhelm Meinhold's popular Amber Witch (1843). More realistic portrayals were located in a deep historical past, as in Harrison Ainsworth's Lancashire Witches (1849) and Elizabeth Gaskill's Lois the Witch (1859), based respectively on the Lancashire witch-trials of 1612 and the Salem trials of 1692, or were romanticized as in the work of Walter Scott or the more subtle nuanced portrayals of his fellow Scotsman James Hogg (Elsley 2012; Moran 2000; Tuczay 2007; Richards 2002; Boatright 1933; Parsons 1946; Briggs 1972; Firor 1931; 
Killick 117-56). It was the regional novelists of the late nineteenth and early twentieth centuries who provided the first nuanced, realistic, and measured depictions of the mundane witch figure and of the nature of popular witchcraft accusations in the nineteenth century, and few returned so repeatedly to the subject in their works as Raymond. His interest in it went beyond its value as a fictional device. He saw witchcraft as an integral aspect of rural culture, and as such gave regular talks on witch beliefs as part of his repertoire of readings from his own work and recitations of William Barnes's poetry, including one of his favourites 'The Witch' ('Taunton Belgian relief lecture' 1914).

Raymond wrote several accounts of witchcraft, witches, and cunning-folk in his volumes of anecdote and reminiscence: The Book of Simple Delights (1906), The Book of Crafts and Character (1907), and Under the Spreading Chestnut Tree (1928). In these vignettes he did not use real names, and the extent to which they are based on real encounters is not always explicit. Yet the veracity of some can be tested. One encounter in Crafts and Character, for instance, concerns a conversation with a man he comes across who is gathering edible snails for sale at Bristol market. When asked what he calls himself, he replies that he told the census enumerator that he was a 'snail merchant'. A search of the English censuses reveals only one person with such an occupation-in 1901 and 1911 one Daniel Williams of Wincanton, Somerset; clearly one and the same man. So we can read Raymond as an ethnographer, and as we shall see, on several occasions references to witchcraft and magic in his novels have their counterparts and origin in his ethnographic encounters.

Notions of who continued to believe in witchcraft in the nineteenth century were often coloured by casual prejudice rather than close observation. Those who feared witches were dismissed as the illiterate, the inhabitants of remote areas, and the elderly. Women were portrayed as particularly prone to 'superstition' and beliefs about witches. While there was certainly no uniformity in the 'mass' experience across social classes in the period, there is evidence that 'members' of the literate and uneducated, the urban and rural, the young and old, and men and women continued to express and act upon the belief in witchcraft and magic right through the nineteenth century. Raymond was careful in reflecting this pervasive concern, noting in one novel that 'the roots of these beliefs lie deeper than the surface ploughing of a superficial education' (Raymond 1911, 157). Men were as 'superstitious' as women in Raymond's novels, for example. Much of the actual talk of bewitchment is conducted by male characters, and in Love and Quiet Life he writes of the character Josiah: 'if ever human soul was a fair prey for witchcraft it was that placid blue-eyed man. He had a natural love for the occult, and drank superstition more readily than cider. He cured warts by burying rusty bacon under the stable door, turned pale if you put the bellows on the table, and once, meeting four magpies on the road to Bridgetown market, he turned back' (Raymond 1894,207). Yet Raymond did have a penchant for portraying his attractive, intelligent leading young women as devout witch believers. In Two Men o' Mendip we are told that for Sophia 'the belief in witchcraft was no unreal fancy to be lightly treated'. Similarly in No Soul above Money, Raymond says of Ursula , 'To the girl, witchcraft was so real a danger, that even to hear the word brought a shudder that crept to her very finger-tips'. Then in Gentleman Upcott's Daughterwe have Ruth Upcott: 'Sometimes misfortune seemed so uncalled for, and always so unexpected, that she dreaded witchcraft; and wondered whether her father's ways ... had offended any one.' (Raymond 1899ㅁa, $266 ; 1899 \underline{a} b$, $129 ; 1893,9)$. There is nothing unrealistic in this, though clearly Raymond thought the 
strong belief in witchcraft, as Hardy did, was a useful device for expressing the elemental, instinctive passions of his red-lipped, hair-tossing heroines.

As we know from the historical sources of the period, witchcraft accusations frequently originated from accumulated personal misfortune, often based around lingering ill health in humans and repeated livestock deaths. In a dairying county like Somerset, failure in the manufacture of butter and cheese was also a common source of suspicion. So in Raymond's No Soul above Money (1899), set in the triangle of remote farmland between Bruton, Castle Cary, and Wincanton, we hear how farmer Malachi Webb comes to believe he has been bewitched following the loss of two cattle, and after suffering an injury when his horse falls into a ditch. The formation of such suspicions is dealt with well in Gentleman Upcott's Daughter. Ebenezer Upcott's social position, and perceived superiority in the village, is undermined by the slow decline of his wagoning business and farm through misfortune, hubris, poor management, and descent into bankruptcy. He gets deeper into debt with his nemesis, the mean-spirited Miller Biddlecombe. One day one of Upcott's carters, John Sprackman, visits the miller and tells him about their recent run of bad luck:

'Ha ! ha ! Luck's first cousin to management. Good or bad, they do show kin. They do feature each other.'

'Ah !' reflected John. 'There's that beyond management. What can 'ee do if you be overlooked? Why, up to Cadbury there were two cows an' a dunkey died in one day. They thought 'twere yew-leaf. Not that, Mr. Biddlecombe, not that. The cows mid; but the wold dunkey werden such a vool as to eat yew-leaf. They were witched right enough. And now there were two cows died o' milk fever last week, an' to-day measter's bay mare gie'd herself a sheäke.' (Raymond 1893, 69).

It is only a while later that John is struck by the conviction that Biddlecome has been 'witching' Upcott. Sprackman then spreads word around the area that Biddlecombe is responsible for Upcott's decline, people begin to avoid the miller, his business suffers, women call their children in when he passes; for Biddlecombe the 'solitude became something awful.' (Raymond 1893, 49, 94, 102).

Raymond is an unusually careful observer of the nuances of popular scepticism and belief. In the exchange above between Sprackman and Biddlecombe, Raymond depicts the forensic way in which witchcraft was deduced. Witchcraft was not automatically suspected. Natural causation, such as yew poisoning, was eliminated first. It is the donkey's natural dietary discernment coupled with the multiple deaths on one day that leads to suspicion. Not all the cow deaths are attributed to the witch either, as two are diagnosed with 'milk fever' or what is known in veterinary science as postparturient hypocalcemia. The miserly farmer Jacob Handsford in No Soul above Moneygleefully tells his daughter Ursula of Malachi Webb's suspicions of witchcraft, but suggests that Webb's negligence, not witchcraft, was probably to blame,

'Ah!' cried her father, again glancing sharply up, 'there's more talk 'an truth in what they do tell up about that. Malachi's ho'se ud a-bin pulled out if he had a-bin about.' ... 'But, hearky, Ursie,' he presently went on, 'the witch don't live that can do un any harm. Not in mind - nor limb - nor pocket. He! he! 'Tis nothing but a fool's tale. So there!' (Raymond 1899âb, 129-30)

These expressions of scepticism do not mean that Handsford does not believe in witchcraft, however. "I wur never witched myself', he tells his daughter, but continues in a lower voice, 'there's they about do love un so well that, if they could witch Jacob 
Handsford, they 'ud never leave un wi' a thread to his back."' Part of his confidence regarding his witchcraft-resistance resides in the contents of his precious notebook, the early pages of which 'were covered thick with charms and cures and recipes intermixed with here and there a maxim of prudent husbandry, culled and copied in full out of some printed book'. Amongst the charms is one 'to ward off the evil eye' (Raymond 1899ab, 128-30).

Turning to Raymond's volumes of rural anecdotes we find one source of his mindfulness in representing the subtleties of popular belief in witchcraft, when he receives a lesson in presumption, in not making assumptions about who believed and who did not based on prejudices, and not assuming there existed a shared monolithic set of popular ideas on the subject. Thus, in his vignette 'Of the Horseshoe on the Door' Raymond relates how he was upbraided by the old village cobbler Hezekiah Hobbes for having nailed a horseshoe to his cottage door. 'But whatever brought your mind to nail such a useless thing as that 'pon your door?' asks Hobbes. Raymond explains that he merely put it there light-heartedly, as it used to be a custom to keep witches away. Hobbes tuts, "tis a poor example to others, all the same. It may mean little to you and me. But consider this. What must the ignorant think to see it there?' Raymond, shamed by this stern enlightened reprimand, embarrassed at his thoughtless encouragement of superstition through his 'antiquarian whim', promises to take it down, and expresses surprise that anybody in the neighbourhood still believed in witchcraft. He is astonished at Hobbes' response:

'Wha-a-at?'

His interruption was loud and sudden, and he leaned forward, quivering with excitement.

'Do people believe it, then?'

'Don't you?'

'No'

'Not believe in what is mentioned in the Word?'

For Hobbes, it was the notion that a horseshoe had any power over witches that was nonsense - not the existence of witches (Raymond 1906, 41-51).2

Hobbes's reference to 'the Word' highlights an important element of nineteenthcentury popular justification for believing in the evils of witchcraft - 'it is in the Bible.' Ruth Upcott resorts to it in her reveries on her family's misfortunes: 'witchcraft is mentioned in the Bible, therefore one must believe in it to some extent' (Raymond1893, 9). In his ethnographic work Raymond also recorded a conversation with a carter who opined, 'nowadays zome do zay there idden no witches. I be zorry for 'em. They mid ha' other book-larnen. But they can't belave the scripshurs' (Raymond 1928, 171). There were two main biblical passages that were pointed out by the 'common folk' when challenged by clergymen, or any other of their 'betters' who patronized them by saying the belief in witchcraft was foolish. First, there was the archetype, the 'Witch of Endor' who called up the ghost of the prophet Samuel in 1 Samuel 28. Then there was the deadly command in the King James' Bible, Exodus 22: 18: 'thou shalt not suffer a witch to live' (Davies 1999, 105; Davies 2013, 65-66). In a society that was becoming predominantly literate, that could read the Bible which all God-fearing Englishmen and women were meant to read and guide their lives by, it was a tall order to then try and argue that the references to witches were matters of mistranslation and metaphor.

Like Hardy before him, Raymond made fictional reference to the strong regional bewitchment tradition of hag-riding. This nocturnal torment is actually a medically 
recognized sleep disturbance episode that was also the origin of the term 'nightmare' (the mare or mara being a female spirit that oppresses people at night). People wake up during a REM sleep episode and find their muscles paralyzed while their central nervous system is hyperactive, so that they can see and hear and feel pain. The experience of paralysis is accompanied by a feeling of pressure on the chest, and in the twilight zone between sleep and wakefulness visual and auditory hallucinations occur. The experience was and is terrifying, and in a culture of fear regarding witchcraft, hallucinations of neighbours or relatives during hag-riding episodes led to accusations of witchcraft. At least five nineteenth-century Somerset court cases involving the assault or abuse of suspected witches derived from the experience of being hag-ridden (Davies, 1996; Davies 1999ab; Davies 2003). In No Soul above Money Malachi Webb complains of being 'hag-rod'. Jacob Handsford reports that, 'He do talk loud that somebody have awitched un - he! He! - an' do come an' ride a ho'se back 'pon the chest of un, ever night of his life, so as he can't sleep a wink' (Raymond 1899ab, 129). A more detailed, graphic account is depicted in Love and Quiet Life:

\begin{abstract}
Abraham was hag-rod every night of his life about two 'in marnen.' A witch came on a 'dree-lagged milken stool, an' sot 'pon Abraham's chest, as Abraham mid be a-lying on the back o' un like.' Whether she turned Abraham on his back like a sheep, or whether he might be so lying at the time, was more than he could swear. But he could take his oath to the three-legged milking stool. For the old hag wouldn't sit still. She bumped up and down for all the world as if she were riding a trot. She had a 'tait' upon that stool, and when it tilted upon one leg you would have thought it was a 'teddy dibble' running between your ribs. But the most wonderfulest thing was, that when Abraham awoke all in a sweat and his chest so sore as if he were black and blue - there was nothing! This treatment had made Abraham most terrible bad in his inside, and brought on a sort of hesitation-like in his stomach, so that he pitched away and got so poor that he were little better than a shadow, and sang the Amens in a voice 'so hoa'se as a crow.' And if that wasn't old Grammer, 'tes a very funny thing. (Raymond 1894, 205) ${ }^{3}$
\end{abstract}

In Hardy's 'The Withered Arm' Rhoda Brook's nightmare, which consists of the young, silk-gowned Gertrude Lodge sitting on her chest and suffocating her, Lodge's features 'shockingly distorted', is presented in tones of Gothic horror. Raymond, on the other hand, takes a lighter, more colourful approach, while nevertheless describing well the deep discomfort of hag-riding attacks. Raymond returned to the condition in his Exmoor novel Revenues of the Wicked(1911), where the heroine Tamsin is told as a child that 'witches can't come and hag-ride 'pon good little girls, if they do never forget to kneel down an' say their prayers afore they do jump into bed':

Matthew, Mark, Luke, and John,

Bless the bed that I lie on.

Six angels about my bed,

Two to foot an' two to head,

An' two to carr' me when I be dead. (Raymond 1911, 104).

This was a variation on a widespread prayer-charm used to ward off night-time terrors. Samuel Taylor Coleridge (1772-1834), for instance, explained to a friend, 'This prayer I said nightly, and most firmly believed the truth of it. Frequently have I (half-awake and half-asleep, my body diseased and fevered by my imagination), seen armies of ugly 
things bursting in upon me, and these four angels keeping them off' (Coleridge 1895, 1: 13).

For those who experienced sleep paralysis and attributed it to witchcraft, one certain way of combatting it was to draw blood from the suspected witch to break the spell. In December 1874, for example, Hester Adams, a seventy-two-year-old widow of Lympsham, was prosecuted for stabbing Maria Pring, aged forty-three, in the hand and face. Adams told the magistrate, 'I can prove she is an old witch, and she has hag-rided me and my husband for the past two years' (Davies 1999ab, 132-33). Numerous such cases occurred in the West Country during the nineteenth century. Hardy referred to the practice in Return of the Native where Susan Nunsuch pricks Eustacia Vye with a knitting needle in church in order to draw blood and thereby break the spell she believes Vye has put on her son. Raymond's one scratching scene, in Love and Quiet Life, is more lighthearted again in its vernacular expression, and concerns the youthful malicious pranks played on the witch-like Grammer Sandboy. On 'panshard day' (Shrove Tuesday) Josiah and his friends throw stones and potsherds at her cottage door. This was the Shrovetide West Country custom of lent-crocking or pan sharding, when boys pelted the homes of unpopular neighbours or those who refused them charity (Hutton 1996, 165-67).When she opens the door muttering maledictions against 'them twoads o' bwoys' one of the potsherds grazes her forehead and draws the 'leastest drap o' blood.' Josiah is relieved because having 'a-drawed blood' he thinks he will be free from her spells forever.

Raymond made less use of cunning folk than Hardy (see White 2010), despite their being significant figures in rural West Country life. This is somewhat surprising considering there were numerous such practitioners around in Raymond's time, such as the Taunton-based Billy Brewer who was famed throughout much of Somerset and East Devon; James Stacey the 'Wizard of South Petherton'; Mother Herne of Charlton Horethorne; and Frederick Culliford of Crewkerne. The latter also held surgeries for his clients at Yeovil market around the time Raymond was living there. Raymond was nevertheless well aware of the influence of cunning-folk, and in his volumes of anecdote and reminiscence related two accounts of their activities as told to him by carters. There are a few brief references here and there in his novels, such as when Malachi Webb is said to have visited a 'wise man up to Blackford' to have the witchcraft removed. The wise man promises to lay Webb's troubles in the Red Sea (Raymond 1899ab, 128-29). One of Raymond's ethnographic conversations also refers to this Red Sea tradition, with a carter relating his experience of a visit to a cunning-man who lived 'at a cross-roads not mor' 'an a mile out o' Yeovil-town'. 'Your wife is auverlooked', he told the carter. 'I can drownd what do do it in the Red Zay' (Raymond 1928, 173; see also Raymond 1907, 121-22). In 1810 the Somerset dialect poet James Jennings (1772-1833), noted the notion that an assembly of cunning-men could conjure troublesome spirits to the Red Sea was 'well known in the county of Somerset' (cited in Binding \& Wilson 2010, 63). Raymond knew Jennings's work, and he may have borrowed the tradition from him, but the Red Sea tradition was quite widespread in popular culture, as well as having a venerable literary history, having been cited in Joseph Addison's Tedworth Drummer (1715) and Matthew Lewis's successful Gothic novel The Monk(1796) (Davies 2007, 76; Binding and Wilson 2010, 62-68). In Somerset and elsewhere during Raymond's day, it was more common for Red Sea spirit-laying legends to concern clergymen who exorcise the spirits rather than cunning-folk who conjure them away. In Ruth Tongue's Somerset Folklore, for instance, there is a story of twelve clergymen who banish the spirit of a wicked old farmer. So powerful was the spirit that a pregnant woman had to 
attend the exorcism, the purity of the unborn child providing the extra boost to pack the spirit off to the Middle East (Tongue 1965, 106-107).

While the professional and often prosperous sort of cunning-folk who made their principal livelihood from magic and called themselves wizards and doctors were largely absent from Raymond's fictional repertoire, he was keen on a more ambiguous figure, the marginal, elderly, female figure who straddled the boundary between wise woman and stereotypical witch. So in Love and Quiet Life, set in the Bridgwater-Cheddar area, we find Grammer Sandboy, a poor elderly woman of 'witch-like ways' from an unpopular family, who lives a makeshift existence from the hedgerows, fields, and woods, and receives charity. Sharp-tongued and prone to 'muttering maledictions', she 'awakened fears even in folk who disclaimed belief in witchcraft' (Raymond 1894, 204). In Revenues of the Wicked the nature of such figures is delineated in more detail in the figure of old Aunt Titcomb, the wise woman of Eddyford: 'many people believed her to be a witch. Perhaps she was neither wise nor a sorceress, but only cunning enough to make the most of her reputation':

\begin{abstract}
Aunt Titcomb not only carried a headful of wonderful and secret things, but a wide experience had taught her much of human nature. Her means of living puzzled everybody. Some said she must be half starved. Others that she had money hidden away and ought not to be allowed parish relief. But with her old age she had found a shrewd and bitter tongue, which feared neither high nor low. The rich encouraged her for the sake of hearing her talk. The humble were careful not to offend her for fear of what she might be able to do. So she did and said as she liked. (Raymond 1911, 152)
\end{abstract}

This type of ambivalent character, which some considered a witch and others a wise woman, had literary precedence. Hardy depicted the figure of Elizabeth Endorfield (note the suggestive surname), in Under the Greenwood Tree (1872), and fellow regional novelist Sabine Baring-Gould created Tamsin Morideg in Mrs Curgenven of Curgenven (1893), who 'probably on account of her peculiar double-irised eyes, but also because of the solitude of her life, far away from all neighbours, was regarded as a wise woman' (Baring-Gould 1893, 75). But such characters, stereotypically but not always elderly widows who lived marginal economic and social lives, who were bestowed with looks or demeanour that reinforced the impression of witchyness or unusual innate power, and who sometimes indulged in fortune-telling and charming, were part of the fabric of real village life and neighbourhood psycho-social dynamics. Baring-Gould wrote about and published a photograph of one such eccentric character called old Mariann Voaden, whom he knew well during his years in Devon. She lived in a tumbledown cottage, possessed healing charms, and was resorted to for the cure of simple ailments. 'How she subsisted was a puzzle to the whole parish', wrote BaringGould. 'But, then, she was generally feared. She received presents from every farm and cottage. Sometimes she would meet a child coming from school, and stay it ... fixing her wild dark eye on it' (Baring-Gould 1898, 1-5; 1908, 75-8).

It is clear from his non-fiction writing that Raymond was drawing upon personal experience and not just received literary tropes in depicting Grammer Sandboy and old Aunt Titcomb, but in historical terms we have to make distinctions between 'witch-like' women and those who were actually publicly accused of and abused for witchcraft. A survey of nineteenth-century Somerset witchcraft disputes, including twenty-six that were heard in court, reveals that few of those accused looked like stereotypical witches - a fact that was sometime remarked upon by journalists reporting the cases. 
They could be young women, middle-aged neighbours, members of the same family, male work colleagues, and people accused out of the blue because they happened to come knocking at the wrong moment when a witch-detection ritual was carried out (Davies 1999ab). These 'real' witches rarely appear in rural novels, and the closest Raymond gets is miller Biddlecombe in Gentleman Upcott's Daughter. In his reminiscence material, though, we find a particularly moving and insightful portrayal of an accused witch with the pseudonym Elizabeth Butts. He encounters her on the road as she grazes her goats. Raymond's gentle interest leads to her unburdening her sadness and bitterness: 'I zaid to myself like here's one that wont go about an' yappy, if I do tell un my secret thoughts'. She did not play the witch or wise woman, did not beg, threaten, or insinuate. She was considered odd for keeping goats, but nothing else marked her out: 'They do zay I be a witch'. She explained:

There was a wicked drinken veller told up lies about me. Vor years an' years I've a turned my head away vrom everybody.... I wur like the rest once. I set my heart 'pon a man but it comed to nothen. Then I did goo out a-nurse-tenden vor years. But I couldn't kip on wi' it. I could'n kip on a-bringen children into th' wordle -vor other wimmen.' (Raymond 1928, 117-22).

\section{Historicity}

Raymond was a poor historical novelist in the sense that he did little to capture or weave into his plots the influence of wider social, economic, religious, and political developments on people's everyday rural lives, even in In the Smoke of War(1896), which plays out during the Civil War. Three of his novels, Two Men o' Mendip, No Soul above Money (1899), and its sequel Jacob and John (1905), are set in the early eighteenth century, though apart from some play with the South Sea Bubble in the latter's plot, for example, there are few touches that are redolent of the time. From a socio-historical and popular belief perspective, No Soul above Money is a little more interesting. The events take place around the time of Queen Anne's War (1702-13). The early eighteenth-century setting is chosen because the story is based on the legend of Jack White's Gibbet. In 1730 Jack White murdered a man (his brother, according to some sources) for money at a crossroads on the road from Wincanton to Castle Cary, near Bratton Seymour. Thomas Hardy knew of the legends that sprang up around the case and recorded in his diary for 1882 that White's gibbet was still standing in the 1830s (Dyke 1833, 4: 334-47; Irving 1922; Hardy 2007, 156). One of these legends, which Raymond uses, is that when White touched the corpse of his victim (his brother) it began to bleed-a sure sign of his guilt. This quasi-official form of judicial ordeal continued into the early eighteenth century. In 1736, for example, newspapers reported that a man in London had recently been acquitted of shooting his wife after the jury suggested he undergo the ordeal. No blood appeared when he held her hands and kissed her several times (Gaskill 2000, 227-29).

The most frequent temporal location for Raymond's novels, though, was the first few decades of the early nineteenth century. Love and Quiet Life depicts village life and religious controversy set around the Catholic Emancipation question and the Swing Riots. The story of Gentleman Upcott's Daughter plays out in the 1820s. Raymond was not alone. Most late nineteenth- and early twentieth-century rural novels portraying witchcraft beliefs were set in this period, such as Mary Webb's Precious Bane, and Hardy's 'The Withered Arm', which was vaguely placed in the period of agrarian unrest around 1830. There is no evidence that these stories were set several generations back primarilybecause the authors wanted to present witchcraft as a fearful reality of the 
past and not the present. Numerous other novels of the genre which have no content regarding popular witchcraft and magic were also set in the period, such as Emma Marshall's Somerset novel Under the Mendips: A Tale (1892) which is set against the Reform Bill riots of 1831.

Yet there is no doubt that witchcraft was a useful device for providing a sense of period. Its efficacy in this respect was dependent on there being a shared perception that the belief was an integral aspect of the 'vanishing countryside' and not the present-of a way of life that was considered to have been in rude health in the early years of the nineteenth century, but now largely irrelevant. The sense of cultural gulf between Georgian and late Victorian times is further reinforced with such distancing phrases as 'in those days' when referring to popular customs and notions. This was not only a novelistic tendency. The autodidact rural working-class autobiographers of the second half of the nineteenth century used witchcraft and 'superstition' as markers of the distance they, and society in general, had progressed from the days of their grandparents or their own youth. This projection of witchcraft into the past was sometimes reinforced by the 'common folk' interviewed by folklorists during the late nineteenth and early twentieth centuries. Some folklorists took at face value the repeated opinions of rural interviewees that 'there used to be plenty of witches about here 50 years ago' or 'witches have all died out', not realizing that this was sometimes a deliberate tactic to evade expressing their belief in witches in the present (Waters 2014). Therefore, the impulse to locate witchcraft accusations two generations earlier was pervasive. If we read fiction as fiction then such temporal warping is not problematic, but if we wish to squeeze Raymond's novels for historical insight then it is. Read Raymond's novels and ethnographic reminiscences and it is clear that he conflated his ethnographic experience in the present with the rural idyll of the past. Other than an absence of reference to the railways, the 1820s world of Gentleman Upcott's Daughter could easily replicate life in 1880s Somerset. Everything he wanted to express about rural Somerset life could have been done in a contemporary setting.

In 1921 a disillusioned Raymond wrote in a letter, 'Old country life has gone ... I have no idyllic instincts left'. He had by this time largely stopped writing. The rustic world he loved had, to his eyes and mind, been ruined and erased by mechanization, by 'rapid locomotion'. 'Until the white steam from the chimney of the "Billy-puffer" was to be seen from the hill taking its course along the valley the pastoral village was as remote as the moorland' (Clark 1933, 191). One response of the rural romantic might have been to immerse himself further in the fictional recreation of the comforting idyllic past of the 1820s. But Raymond's disillusionment and abandonment of his literary career shows just how much his historical novels were effectively novels of contemporary rural life. He could write no more because the source of his inspiration had finally been crushed by the bulldozer of modernity, or so he perceived.

According to Raymond, 'superstitions' of all kinds had flourished up until 1914, but by the end of the First World War they had evaporated. Yet, the sources indicate magical charms and remedies continued to be used by many Somerset folk after 1918, and witchcraft was still quite widely believed in in Somerset during Raymond's final years. His friend Evelyn Clark wrote in 1932 that 'belief in witchcraft and all the rest of it-still survives in Somerset. I have lately heard stories of witchcraft which were undoubtedly believed in by the narrator' (Clark 1932, 4). Somerset courts continued to deal with witchcraft disputes into the 1920s. In 1926 the Glastonbury Petty Sessions, heard the case of Albert Marsh, a seventy-seven-year-old resident in the local almshouse who accused the husband of another resident, Sarah Wilkins, of visiting him 
as a witch in spirit form. Sarah Wilkins assaulted him for making such accusations. As Marsh told the magistrate, 'I told her her husband came to my home as a witch, and so he did. I was sitting in the chair, he came with his face to me. I spat at it, and went at it, and he went away like a ball of smoke'. When asked how he knew it was Mr Wilkins, Marsh replied, 'because of the head and beard. There was nothing else but that' ('Witchcraft in Somerset' 1926). In 1929 a long-standing dispute between two neighbours, the Sheppards and the Locks, who lived on the peat moors between Langport and Aller, erupted in an accusation of witchcraft. The Sheppards, like Gentleman Upcott and Malachi Webb, had experienced a series of misfortunes. They had lost two horses and a cow, and George had been ill for a while. On the 25 April they encountered Reuben Lock as they returned from milking their cows on the moor. George shouted 'You! You hag-riding __ and your ___ hag-riding old wife', took the yoke holding his milk pails from around his neck and threatened to beat Reuben's head with it (Davies 1999ab, 153-6). These are cases of rural dispute that could have come straight out of Raymond's novels of early nineteenth-century Somerset life, but Raymond ceased literary interest in them because he believed in the myth of a vanished rural customary world that he had helped create.

As well as temporality, the other issue of historicity raised by exploring Raymond's work is that of realism. How close to the reality of rural life was Raymond in his novels? In his innovative comparison of Hardy's fiction with the realities of rural society in Dorset, Keith Snell concludes that Hardy by-passed many of the 'important but transient issues of his day', such as class tensions, the poor law, insanitary conditions, and wage disputes, yet with regard to feelings of personal alienation and marital estrangement he was responsive to the broad social history of the period (Snell 1985, chap. 8). ${ }^{4}$ Raymond was even less concerned with the 'issues of the day' than Hardy, and consequently a similar exercise to that conducted by Snell regarding Somerset would be damning. While he presented a tempered idyll with respect to intimate psychological misery born of miserliness, neighbourly jealousy, and obsession with money, Raymond declined to explore environmental and macro-level hardships. Despite a typhoid epidemic killing his mother and sister and nearly taking him too, Raymond was not interested, for instance, in depicting the poor sanitary conditions and the resulting epidemics in the villages he was familiar with, such as the diphtheria outbreak in Corfe in 1881. He was naïve in his view of the immobility of the rural Somerset population and the degree of population movement in the county prior to the railways. The census reveals that the snail merchant he wrote about, and whose speech he expressed in a Somerset accent, had been born in Arlesey, Bedfordshire, and his wife in Suffolk.

Of course, as Snell recognized, during the years Hardy was writing novels he was driven by his art and not the purpose of realism, and so too was Raymond in his more modest way. The problem arises when the rural idyllists expressly argued that they were aiming for reality rather than a verisimilitude. In 1912, Hardy wrote that he had attempted to produce 'a fairly true record of a vanishing life', and likewise years after he stopped writing novels Raymond wrote how he and others had attempted to capture what 'only those who are "up in years"' could remember about 'the old world and its folk, their ancient customs and their original ways' (Plietzsc 2004, 41; Clark 1933, 187). That memory was partial. But we are concerned not with the socio-economic realism of Hardy and Raymond here, but the issue of witchcraft belief and beliefs.

As has been explored, Raymond's work is successful in accurately reflecting aspects of regional witchcraft belief and the dynamics of witch accusations. In this 
respect his idylls provide a degree of realism about rural life that Zola's harsh Darwinian portrayal in La Terre does not. La Terre brings you close to the poverty, class tensions, and brutality of agricultural labouring lives, but is largely devoid of the idiom, beliefs, and customary practices that were integral to that existence. Still, Raymond's portrayal is deeply moderated by his romanticism. He expressed the loneliness of those accused of witchcraft in his depictions of miller Biddlecombe and his account of Elizabeth Butts, but nowhere did he explore the viciousness, deadliness, psychological terror, tragedy, and legal consequences that ensued from accusations-the suicides, the beatings, the mental illness, and even murder. Consider the prosecution in 1905 of Frances Jane Smith, of Pitminster, for threatening to stab another woman. It emerged that she and her husband had farmed at Honiton, Devon, until they lost a good deal of their cattle. Some gypsies told them that they had been bewitched and that the only way to protect themselves from the witch was for Frances to wear various trinkets, cheap rings, and curious garb, for which she evidently paid the gypsies considerable sums of money. Well-educated, Frances and her husband spent much of their savings in this way so that he was now working as a farm labourer. Frances took to drink and her mental state deteriorated under the fear and obsession. She had become a peculiar sight in the locality, wearing her tam-o'shanter decorated with large coloured feathers, a large check jacket and orange dress, while around her neck hung an iron padlock and a pair of scissors. From her waist dangled brightly coloured rags and a bit of the Union Jack. The court had her removed to Cotford asylum (Taunton Courier, 6 September 1905;

Western Times, 5 September 1905). Eleven years later, Philip George Hill, aged fiftytwo, a farmer at Edithmead, Burnham, shot dead his eighty-one-year-old neighbour Daniel Lawrence for bewitching him. This is a sad Somerset claim to fame; it is the only case of witch-shooting in Britain, though such cases have been well recorded in twentieth-century America and France. Hill told the arresting officer, 'I have a lot of worry here. He has bewitched my child and my pony. You don't believe in witchcraft, and the Government don't, but I do'. Found guilty at the Autumn Assizes, Hill was declared to be of unsound mind when he committed the act (Taunton Courier, 25 October 1916).

While witchcraft gave authenticity to the past, too much authenticity would have undermined the idyll. Neither did the continuance of witchcraft belief and accusations fit the model of a vanished world. Raymond was not wrong in stating that the Somerset countryside, and the lives of the communities who lived in it, were being transformed during his lifetime. Mechanization, the globalization of food production, sanitary regulations, and other social and economic developments were creating new realities. Witchcraft too was becoming less relevant, in part because of these changes. The frustration is that Raymond did not apply his knowledge, compassion, and sensibilities to representing this in all its rich complexity in his work rather than reinforcing a verisimilitude of the idealized rural past.

\section{Notes}

1. This article is the result of an interdisciplinary collaborative project funded by a British Academy Small Grant. We thank the British Academy, and the project researcher Gregory Leadbetter. We also thank the helpful comments of the journal's reviewers.

2. Raymond told a version of this encounter to his friend Evelyn Clark (Clark 1932, 5).

3. Raymond attributes the same basic details to a cobbler of his acquaintance in a later book of reminiscences (Raymond 1906, 50). 
4. For a critique see Plietzsc 2004.

\section{References Cited}

'The Author Who Avoids the Cities'. Western Morning News, 18 December 1928.

Baker, Ernest Albert. The History of the English Novel. Vol. 9. London: Witherby, 1938.

Baring-Gould, Sabine. Mrs Curgenven of Curgenven. London: Methuen, 1893.

-----. An Old English Home and its Dependencies. London: Methuen, 1898.

-----. Devonshire Characters and Strange Events. London: J. Lane, 1908.

Bearman, C. J. "'Who were the Folk?" The Demography of Cecil Sharp's Somerset Folk Singers'. Historical Journal 43, no. 3 (2000): 751-75.

Bennett, Gillian. 'Geologists and Folklorists: Cultural Evolution and "The Science of Folklore”'. Folklore 105 (1994): 25-37.

Blum, Jerome. 'Fiction and the European Peasantry: The Realist Novel as a Historical Source'. Proceedings of the American Philosophical Society 126, no. 2 (1982): 122-39.

Binding, C. J., and L. J. Wilson. 'Ritual Protection Marks in Wookey Hole and Long Hole, Somerset'. Proceedings of the University of Bristol Speleological Society 25, no. 1 (2010): 46-72.

Boatright, M. C. 'Witchcraft in the novels of Sir Walter Scott'. University of Texas Studies in English 13 (1933): 95-115.

Boyes, Georgina. The Imagined Village: Culture, Ideology and the English Folk Revival. Manchester: Manchester University Press, 1993.

Briggs, K. M. 'Folklore in Nineteenth-Century English Literature'. Folklore 83, no. 3 (1972): 194209.

Burchardt, Jeremy. Paradise Lost: Rural Idyll and Social Change since 1800. London: I. B. Tauris, 2002.

C. D. B. 'Walter Raymond of Somerset'. Western Morning News, 9 January 1934, 11.

Clark, Evelyn V. Walter Raymond: The Man-His Work and Letters. London: Dent, 1933.

----.. 'Superstition in Somerset'. Somerset Countryman 2, no. 1 (1932): 4-5: If this is a magazine, as opposed to a newspaper, are there any page numbers?

Coleridge, E. H., ed. Letters of Samuel Taylor Coleridge. 2 vols. London: Heinemann, 1895.

Davies, Owen. America Bewitched: The Story of Witchcraft after Salem. Oxford: Oxford University Press, 2013.

-----. The Haunted: A Social History of Ghosts. Basingstoke: Palgave Macmillan, 2007. 
-----. 'The Nightmare Experience, Sleep Paralysis and Witchcraft Accusations'. Folklore 114, no. 2 (2003): 181-203.

-----. A People Bewitched: Witchcraft and Magic in Nineteenth-Century Somerset. Bruton: privately printed, 1999a.

Witcheraft, Magic and Culture, 1736-1951. Manchester: Manchester University Press, 1999a.

-----. A People Bewitched: Witchcraft and Magic in Nineteenth-Century Somerset. Bruton: privately printed, 1999b. [ Witchcraft, Magic and Culture, 1736-1951. Manchester: Manchester University Press, 1999b. these should go the other way round (a/b) because if they are the same date, then the alphabetization of the title kicks in and $P$ comes before $W$. The in-text citations will need to be adjusted]

-----. 'Hag-riding in Nineteenth-Century West Country England and Modern Newfoundland: An Examination of an Experience-Centred Witchcraft Tradition'. Folk Life 35 (1996): 36-53.

Dyke, George C. 'Jack White's Gibbet'. In The Republic of Letters: A Selection in Poetry and Prose, 4 vols, edited by Alexander Whitelaw, 334-47. Glasgow: Blackie \& Son, 1833.

Elsley, Susan Jennifer. 'Images of the Witch in Nineteenth-Century Culture'. PhD Thesis, Liverpool University, 2012.

Firor, Ruth. Folkways in Thomas Hardy. Philadelphia: University of Pennsylvania Press, 1931.

Gaskill, Malcolm. Crime and Mentalities in Early Modern England. Cambridge: Cambridge University Press, 2000.

Hardy, Thomas, and Florence Hardy. Thomas Hardy. Ware: Wordsworth, 2007. Originally published in 1928 and 1930.

Harker, Dave. Fakesong: The Manufacture of British 'Folksong', 1700 to the Present Day. Milton Keynes: Open University Press, 1985.

Howkins, Alun. 'The Discovery of Rural England'. In Englishness: Politics and Culture 18801920, edited by Robert Colls and Philip Dodd, 62-89. London: Croom Helm, 1986.

Hutton, Ronald. The Stations of the Sun: A History of the Ritual Year in Britain. Oxford: Oxford University Press, 1996.

Irving, H. B. 'Jack White’s Gibbet'. Somerset Year Book(1922): 20.

Jennings, James. Poems, consisting of the mysteries of Mendip, the magic ball. London: privately printed, 1810 .

Keith, W. J. 'Thomas Hardy and the Powyses'. In Thomas Hardy Reappraised: Essays in Honour of Michael Millgate, edited by Keith Wilson, 270-85. Toronto: University of Toronto Press, 2006.

Killick, Tim. British Short Fiction in the Early Nineteenth Century: The Rise of the Tale. Aldershot: Ashgate, 2008.

Lawrence, Berta. 'Thomas Hardy \& Walter Raymond'. Thomas Hardy Journal 2 (1986): 35-38. 
Moran, Maureen F. “'Light no Smithfield Fires”: Some Victorian Attitudes to Witchcraft'. Journal of Popular Culture 33, no. 4 (2000): 123-51.

Panton, Jane Ellen. A Gentlewoman's Home: The Whole Art of Building, Furnishing, and Beautifying the Home. London: 'The Gentlewoman' Offices, 1896.

Parsons, Coleman 0. 'Stevenson's Use of Witchcraft in "Thrawn Janet"'. Studies in Philology 43 (1946): 551-71.

Plietzsc, Birgit. The Novels of Thomas Hardy as a Product of Nineteenth-Century Social, Economic, and Cultural Change. Berlin: Tenea Verlag, 2004.

Raymond, Walter. Gentleman Upcott's Daughter. 2nd ed. London: Unwin, 1893.

----. Love and Quiet Life: Somerset Idylls. London: Hodder and Stoughton, 1894.

----. No Soul above Money. London: Longmans, Green, 1899a.

Two Men o'Mendip. London: Longmans, 1899a.

----. Two Men o' Mendip. London: Longmans, 1899b.No Soulabove Money. London: Longmans, Green, 1899b. [same thing here: N before T; so please swap and then change all in-text citations to match]

----. The Book of Simple Delights. London: Hodder \& Stoughton, 1906.

-----. The Book of Crafts and Character. London: Hodder \& Stoughton, 1907.

----. Revenues of the Wicked. London: J.M. Dent \& Sons, 1911.

-----. Under the Spreading Chestnut Tree. London: Folk Press, 1928.

Richards, Jeffrey. "'The Lancashire Novelist" and the Lancashire Witches'. In The Lancashire Witches: Histories and Stories, edited by Robert Poole, 166-88. Manchester: Manchester University Press, 2002.

Snell, Keith. 'The Regional Novel: Themes for Interdisciplinary Research'. In The Regional Novel in Britain and Ireland: 1800-1990, edited by Keith Snell, 1-53. Cambridge: Cambridge University Press, 1998.

----. Annals of the Labouring Poor: Social Change and Agrarian England, 1660-1900. Cambridge: Cambridge University Press, 1985.

‘Taunton Belgian Relief Lecture'. Taunton Courier, 9 December 1914.

Tongue, Ruth. Somerset Folklore. London: Folk-Lore Society, 1965.

Tuczay, Christa. 'The Nineteenth Century: Medievalism and Witchcraft'. In Witchcraft Historiography, edited by Jonathan Barry and Owen Davies, 52-68. Basingstoke: Palgrave Macmillan, 2007.

Warner, Charles Dudley, ed. A Library of the World's Best Literature: Synopses of Famous Books. Vol. 44. New York: J. A. Hill, 1896. 
Waters, Thomas. "They seem to have all died out": Witches and Witchcraft in Lark Rise to Candleford and the English Countryside, c. 1830-1930'. Historical Research 87 (2014): 134-53.

White, Simon J. 'Folk Medicine, Cunning-Men and Superstition in Thomas Hardy's "the Withered Arm"'. In Demons of the Body and Mind: Essays on Disability in Gothic Literature, edited by Ruth Bienstock Anolik, 68-80. Jefferson: McFarland, 2010.

'Witchcraft in Somerset'. Western Gazette, 29 January 1926.

\section{Biographical Notes}

Owen Davies is Professor of Social History at the University of Hertfordshire, and has published widely on the history of witchcraft, magic and ghosts.

Simon White is Reader in Romantic \& Nineteenth-Century Literature at the University of Hertfordshire. He works on the representation of rural life and the rural community, particularly with regard to witchcraft and magic. 